\title{
Interaction of initial seedling diameter, fertilization and weed control on Douglas-fir growth over the first four years after planting
}

\author{
Robin Rose*, J. Scott KeTCHUM \\ Vegetation Management Research Cooperative, College of Forestry, Oregon State University, Corvallis, OR 97331, USA
}

(Received 24 June 2002; accepted 28 February 2003)

\begin{abstract}
Planting larger stock, fertilization and added years of weed control are often employed to increase growth rate of plantations. We evaluated these techniques using a replicated factorial study design repeated in two diverse locations in western Washington State, USA. Two different sizes of planting stock, fertilizing at planting and in the following year, and two or three years of weed control were tested. No significant interactions among the treatment levels were found with all treatments influencing Douglas-fir growth in an additive manner. Fourth year stem volume gains were greatest from planting larger initial stock: planting seedlings $2 \mathrm{~mm}$ larger in basal diameter resulted in fourth-year stem volume gains of $35 \%$ and $43 \%$. The fertilization treatments used produced early gains, but they were short lived. The third-year weedcontrol treatment had no observable effect on fourth-year stem volume or on volume growth in years three or four.
\end{abstract}

free-to-grow / herbicide / controlled-release fertilizer / nutrition

Résumé - Interaction du diamètre au collet initial des plants, de la fertilisation et du contrôle de la végétation concurrente avec la croissance du Douglas pendant les quatre années suivant la plantation. Pour accélérer la croissance des plantations, on fait souvent appel à des techniques telles que l'emploi de plants plus gros, la fertilisation ou le contrôle de la végétation concurrente pendant plusieurs années. Nous avons évalué ces techniques au moyen de dispositifs factoriels avec répétitions installés dans deux stations de l'ouest de l'État de Washington aux USA. On a testé les options suivantes : deux catégories de plants pour leurs dimensions, fertilisation à la plantation et l'année suivante, et deux ou trois ans de contrôle de la végétation concurrente. Aucune interaction significative entre traitements n'a pu être mise en évidence. Tous les traitements agissant sur la croissance du Douglas le font de manière additive. La quatrième année, les gains de volume des tiges sont les plus élevés avec le matériel végétal initial le plus gros. Avec des plants dont le diamètre au collet est de $2 \mathrm{~mm}$ plus élevé, on obtient la quatrième année des gains sur le volume de tige de 35 et $43 \%$. Les traitements de fertilisation utilisés se sont traduits par des gains au départ, mais de courte durée. Le contrôle de la végétation de la troisième année n'a pas eu d'effet observable sur le volume des tiges de la quatrième année ou sur la croissance en volume des années trois et quatre.

croissance libre / herbicide / épandage contrôlé de fertilisation / nutrition

\section{INTRODUCTION}

The use of vigorous nursery stocktypes and aggressive early weed control have resulted in nearly universal Douglasfir (Pseudotsuga menziesii (Mirb.) Franco) seedling survival for all practical purposes on productive forest sites within the Pacific Northwest Region. The current issue is how to attain the greatest seedling growth within the first few years after outplanting. This impetus is in part due to regional regulations requiring lands adjacent to planned harvest units within an ownership to have seedlings "free to grow" prior to harvest [24]. Additionally, the potential economic benefit from faster early plantation growth that may result in shortened rotation ages has greatly increased the interest in pushing young plantations to grow as fast as possible.

The traditional silvicultural tools used to enhance early Douglas-fir plantation growth have been planting a target seedling, improved genetics, weed control, and fertilization [30]. A variety of studies have demonstrated that planting stock with larger initial stem diameter can accelerate early plantation survival and growth $[11,22,41]$. Similarly, several studies have demonstrated positive survival and growth responses of Douglas-fir to site preparation and first-year and sometimes second-year herbaceous weed control $[6,16,20$, 28, 42]. The response to early fertilization has been less consistent, with examples of positive, negative, or mixed

* Corresponding author: robin.rose@ orst.edu 
Table I. Results of soil chemical nutrient analysis at the Orting and Belfair sites.

\begin{tabular}{|c|c|c|c|c|c|c|c|c|c|c|c|c|c|}
\hline $\begin{array}{l}\text { Site } \\
\text { Soil horizon }\end{array}$ & $\begin{array}{c}\text { CEC } \\
\text { meq/100 g }\end{array}$ & $\mathrm{pH}$ & $\begin{array}{c}\text { Total N } \\
\%\end{array}$ & $\begin{array}{c}\mathrm{NH}_{4} \\
\mathrm{mg} \mathrm{kg}^{-1}\end{array}$ & $\begin{array}{c}\mathrm{P} \\
\mathrm{mg} \mathrm{kg}{ }^{-1}\end{array}$ & $\begin{array}{c}\mathrm{K} \\
\mathrm{mg} \mathrm{kg}{ }^{-1}\end{array}$ & $\begin{array}{c}\mathrm{Ca} \\
\mathrm{meq} / 100 \mathrm{~g}\end{array}$ & $\begin{array}{c}\mathrm{Mg} \\
\mathrm{meq} / 100 \mathrm{~g}\end{array}$ & $\begin{array}{c}\mathrm{Cu} \\
\mathrm{mg} \mathrm{kg}^{-1}\end{array}$ & $\begin{array}{c}\mathrm{Fe} \\
\mathrm{mg} \mathrm{kg}^{-1}\end{array}$ & $\begin{array}{c}\mathrm{Zn} \\
\mathrm{mg} \mathrm{kg}^{-1}\end{array}$ & $\begin{array}{c}\mathrm{Mn} \\
\mathrm{mg} \mathrm{kg}^{-1}\end{array}$ & $\begin{array}{c}\text { B } \\
\mathrm{mg} \mathrm{kg}^{-1}\end{array}$ \\
\hline \multicolumn{14}{|l|}{ Orting } \\
\hline A-horizon & 16 & 5.6 & 0.46 & 5.6 & 10 & 78 & 1.4 & 0.4 & 0.56 & 45.8 & 0.88 & 4 & 0.4 \\
\hline B-horizon & 8.9 & 5.8 & 0.23 & 2.4 & 9 & 43 & 0.3 & 0.2 & 0.2 & 15.6 & 0.02 & 0.9 & 0.2 \\
\hline \multicolumn{14}{|l|}{ Belfair } \\
\hline A-horizon & 19.9 & 5.2 & 0.32 & 8 & 30 & 74 & 3.5 & 0.9 & 0.86 & 136 & 7.66 & 153 & 0.5 \\
\hline B-horizon & 5.4 & 5.6 & 0.08 & 2 & 36 & 31 & 0.3 & 0.1 & 0.54 & 44.4 & 0.4 & 5 & 0.2 \\
\hline
\end{tabular}

responses reported by a number of investigators $[5,7,23,29$, $39,40]$.

In the Pacific Northwest, the bulk of the studies evaluating reforestation techniques have tended to examine a single silvicultural approach at a time. For example, several studies have examined the impact of different weed control regimes on growth $[4,10,37,38]$, or the impact of various fertilizers [5, 40]. Fewer studies can be found that evaluated the interactive effect of more than one silvicultural treatment, such as the effect of weed control in concert with fertilization [23, 29, 44]. Of those studies that examined how seedling characteristics might impact growth, most were restricted to examining the effects of different stock sizes and types on early growth, although some have included site characteristics as an additional factor $[8,9,26]$.

In this paper we present results from two independent studies that used factorial combinations of three of these early silvicultural approaches: stock size, weed control, and fertilization. We evaluated past responses to the above silvicultural treatments and chose those that resulted in the greatest success. We then combined them into a single study to evaluate the interactive effects of different combinations of these approaches.

\section{METHODS}

\subsection{Study areas}

Two independent experiments were established in Washington State: one on the western slope of Mount Rainier, east of the town of Orting, and the other on the western coast of the Puget Sound near the town of Belfair. Both sites had been harvested during the summer of 1996; the treatment regimes were established in spring 1997.

Prior to harvest, the Orting site supported a well-stocked, naturally regenerated second-growth stand of Douglas-fir with a small component of western hemlock (Tsuga heterophylla (Raf.) Sarg.) and western redcedar (Thuja plicata Donn ex D. Don). The study site is at an elevation of $523 \mathrm{~m}(1700 \mathrm{ft})$ and on generally flat ground that allowed for whole-tree skidder yarding. This resulted in little slash and several skidder trails randomly distributed across the site. Soils are in the Zynbar series, which are medial frigid Entic D loam soils averaging $152.4 \mathrm{~cm}$ (60 in) in depth. The site receives approximately $172.7 \mathrm{~cm}$ (68 in) of rainfall each year with only $10 \%$ of this coming during the summer months. Kings 50 year site index is $37.8 \mathrm{~m}(123 \mathrm{ft})$. Soil samples of the A and B horizons were collected in the first year of establishment and analyzed for nutrient status. The analysis results are shown in Table I.

Before harvest, the Belfair site consisted of a well-stocked Douglas-fir stand with a minor component of western hemlock, western white pine, and lodgepole pine. The site was located on a flat to undulating slope at an elevation of 400 feet. It was shovel logged with slash piled and left on the site. Soils are derived from a glacial till parent material and are gravely to very gravelly sandy loams. They are moderately well drained and are $58 \mathrm{~cm}$ to $102 \mathrm{~cm}$ in depth. Precipitation averages $135 \mathrm{~cm}$ per year with $94 \%$ of the moisture falling in the fall, winter and spring months. Fifty year Kings site index is $32.9 \mathrm{~m}$. Soil nutrient analysis is shown in Table I.

\subsection{Design}

Each site was considered an independent experiment with both utilizing the same randomized block design. Two levels of weed control, two levels of initial stock sizes, and three levels of fertilization were applied factorially providing twelve separate treatments. There were five blocks at the Belfair site, but only four blocks at the Orting site. Each treatment unit (square plot) within a block consisted of 36 trees planted on a grid spacing of $2.44 \mathrm{~m} \times 2.44 \mathrm{~m}(8 \mathrm{ft} \times 8 \mathrm{ft})$. A row of buffer trees was included to separate contiguous plots and encircled plots on the outside edge of a block. All seedlings were planted in early February 1997 at both sites.

\subsection{Vegetation control treatments}

Two vegetation control treatments were used: control of all vegetation for two years and control of all vegetation for three years. Vegetation control was accomplished with herbicides, the goal being to maintain operational weed-free conditions as much as possible for either two or three years, depending on the treatment. The herbicides used and rates varied between the two sites due to different target weed communities and expected efficacy of treatment.

The Orting site received a helicopter applied broadcast spray with $210 \mathrm{~g} / \mathrm{ha}$ of Oust ${ }^{\circledR}$ and $0.73 \mathrm{~L} / \mathrm{ha}$ of Transline ${ }^{\circledR}$ on April 24th 1997. In Sept. 1997, a directed spray of $2 \%$ Accord $^{\circledR}$ in water was applied by backpack sprayer to all hardwoods (cottonwood, alder, elderberry, blackberry) and to western brackenfern (Pteridium aquilinum (L.) Kuhn) and western swordfern (Polystichum munitum (Kaulf. Presl.) invading the site. A follow-up treatment (a $4 \%$ solution of Garlon ${ }^{\circledR}$ in Web Oil ${ }^{\circledR}$ ) for the remaining hardwoods was applied in April 1998. No herbaceous control herbicides were applied in year two. In the spring of the third year a broadcast application of $4.67 \mathrm{~L} / \mathrm{ha}$ Velpar and $140 \mathrm{~g} /$ ha Oust ${ }^{\circledR}$ was applied by backpack to the three-year vegetation-control plots. 
The Belfair site received a $245 \mathrm{~g} /$ ha broadcast treatment of Oust ${ }^{\circledR}$ using backpack sprayers in mid April 1997. The site was treated again in early April 1998 with a $3.5 \mathrm{~L} / \mathrm{ha}$ Velpar broadcast treatment and a directed application of a $5 \%$ solution of Garlon ${ }^{\circledR}$ in Web Oil ${ }^{\circledR}$ on all salal (Gaultheria shallon Pursh), Oregon grape (Mahonia aquifolium (Pursh) Nutt.) and evergreen huckleberry (Rubus laciniatus Willd.) plants within the plot areas. The third-year weed-control treatment consisted of another 3.5 L/ha Velpar application in early April 1999 to the appropriate plots.

\subsection{Stem diameter size class treatments}

The caliper size-class treatments consisted of a small- and largediameter classes, sorted at the nursery from seedlings coming from the same beds. The seedlings used were grown at two separate nurseries, the trees for Orting at one and those for Belfair at another. Prior to lifting, representative samples of seedlings were measured at both nurseries. From these data two diameter-sort size ranges were determined, which encompassed $60 \%$ of the seedlings grown in the beds, but did not include the extremely small or extremely large seedlings from the population. The large diameter class for the Orting site was $10-12 \mathrm{~mm}$ and for Belfair, it was $8-10 \mathrm{~mm}$. The small diameter class at Orting was $6-8 \mathrm{~mm}$, and at Belfair, it was 5-7 mm. Seedlings that were either smaller or larger than the two size groupings were returned to the nursery for planting elsewhere.

\subsection{Fertilization treatment}

The three fertilizer treatments were a no-fertilizer treatment (NF), fertilization at the time of planting $(1 \mathrm{~F})$, and an additional fertilization following the first growing season $(2 \mathrm{~F})$. The $1 \mathrm{~F}$ treatment was accomplished by placing $70 \mathrm{~g}$ of a specially prepared 10-21-6 mix (7 g N; $9.2 \mathrm{~g} \mathrm{P} ; 5 \mathrm{~g} \mathrm{~K})$ of the O.M. Scotts \& Sons Co. controlledrelease fertilizer in the hole at planting. This fertilizer released nutrients gradually over a six to eight month period. A thin layer of soil was placed between the roots of the planted seedlings and the fertilizer in the bottom of the planting hole to prevent root burn. The $2 \mathrm{~F}$ treatment used the same $70 \mathrm{~g}$ of the 10-21-6 mix, which was dibbled into a slit $12 \mathrm{~cm} \mathrm{(5} \mathrm{in)} \mathrm{in} \mathrm{depth,} \mathrm{as} \mathrm{close} \mathrm{to} \mathrm{the} \mathrm{main} \mathrm{stem} \mathrm{as} \mathrm{possible}$ without causing damage to the seedling, generally 10 to $15 \mathrm{~cm}$. This treatment was applied in December after the first growing season.

\subsection{Measurements}

\subsubsection{Seedlings}

In March of 1997 height and basal diameter $(10 \mathrm{~cm}$ above groundline) all the seedlings in the plots were measured. At this time mortality was also recorded. Seedlings were again measured for height and basal diameter in the fall after height growth had ceased for each of the next four years. From these measures, stem volume was calculated using the formula for a cone, in $\mathrm{cm}^{3}$ :

$$
\text { volume }=\frac{\pi \times\left(\text { diameter }^{2}\right) \times \text { height }}{12} .
$$

\subsubsection{Foliage nutrients}

Foliage samples were collected from eight randomly selected seedlings in each plot after the first and second year of growth. The samples were collected in fall from lateral branches in the upper third of the crown and consisted of only the current year's growth. The needles were removed from the samples and pooled together by plot. Dry weight of a random 100 needles were determined for each plot and the samples were dried, ground, and sent to a lab for analysis of the concentrations of all major and micro nutrients with standard laboratory procedures.

\subsubsection{Vegetation}

The percent cover of vegetation in a 1-m radius plot around each seedling at both sites was visually estimated in all four years of the study. These estimates were performed in mid-July, when the greatest level of vegetation cover was expected to occur on the sites. The most predominant species were recorded in each plot, as was a modal height of the vegetation in the plot.

\subsection{Analysis}

Analysis of variance was used to compare differences in fourthyear stem volume and percent mortality at each study site independently. Additional ANOVA analyses were performed on yearly stem diameter growth, height growth, stem volume growth, vegetation cover, and vegetation height by year, independently by site. Residuals of all analyses were examined for lack of normality and equal variance, and required no transformations. All analyses were performed with the factorial treatment structure such that interactive effects among treatment could be examined. Means were compared using Fishers least significant difference tests. In cases when no significant interactions between main treatment factors were found means for a treatment factor were pooled across the other two factors for this test.

Foliar nutrient concentrations and needle weights were analyzed with ANOVA using the first and second years. Orthogonal contrasts (shown below) were used to compare differences between the stock size treatments, vegetation control treatments, and the fertilization treatments for all the major and minor nutrients.

Orthogonal contrasts examined:

- Large vs. small diameter sort,

- 2 years weed control vs. 3 years weed control,

- NF vs. fertilization,

$-1 \mathrm{~F}$ vs. $2 \mathrm{~F}$ treatment.

\section{RESULTS}

Results were remarkably similar between the two different sites, given the differences in soils and locations. No consistent interactions were found among any of the treatment factors. For both sites the $p$ values for all interactions ranged from 0.0783 to 0.9204 . The $\mathrm{V} \times \mathrm{F} p$ value was 0.0783 for height. The next closest was $0.19(\mathrm{~S} \times \mathrm{V} \times \mathrm{F})$ for diameter, but all other $p$ values were 0.27 and above for all responses. This suggests that the response to treatments was additive in nature. For example, the benefit derived from planting larger stock was similar regardless of fertilizer or weed control treatment and vice versa. This allows for results of each treatment factor to be presented independently of the others. Treatment responses varied by site and are presented separately.

\subsection{Orting}

\subsubsection{Seedling mortality}

First-year seedling mortality averaged less than $2 \%$ for all treatments. Mortality increased through year four and by initial 
Table II. Mean fourth-year diameter, height, stem volume, and mortality by treatment factor for each year of the study and by site.

\begin{tabular}{|c|c|c|c|c|c|c|c|}
\hline \multirow{2}{*}{ Parameter/treatment } & \multicolumn{2}{|c|}{ Size } & \multicolumn{3}{|c|}{ Fertilization } & \multicolumn{2}{|c|}{ Vegetation control } \\
\hline & Small & Large & $\mathrm{NF}$ & $1 \mathrm{~F}$ & $2 \mathrm{~F}$ & 2-years & 3 -years \\
\hline \multicolumn{8}{|l|}{ Orting Site } \\
\hline Diameter (mm) & $34.6 \mathrm{a}^{1}$ & $39.0 \mathrm{~b}$ & $36.0 \mathrm{a}$ & $37.4 \mathrm{a}$ & $37.1 \mathrm{a}$ & $35.2 \mathrm{a}$ & $38.4 \mathrm{~b}$ \\
\hline Height $(\mathrm{cm})$ & $196.7 \mathrm{a}$ & $223.2 b$ & $205.6 \mathrm{a}$ & $213.8 \mathrm{a}$ & $210.5 \mathrm{a}$ & $212.6 \mathrm{a}$ & $207.3 \mathrm{a}$ \\
\hline Stem volume (cc) & $775.2 \mathrm{a}$ & $1043.2 b$ & $826.4 \mathrm{a}$ & $961.2 \mathrm{a}$ & 939.9a & $832.8 \mathrm{a}$ & $985.5 \mathrm{~b}$ \\
\hline Mortality (\%) & $8.9 \mathrm{a}$ & $5.2 \mathrm{~b}$ & $3.8 \mathrm{a}$ & $6.3 \mathrm{a}$ & $11.1 \mathrm{~b}$ & $6.3 \mathrm{a}$ & $7.9 \mathrm{a}$ \\
\hline \multicolumn{8}{|l|}{ Belfair Site } \\
\hline Diameter (mm) & $34.2 \mathrm{a}$ & $39.0 \mathrm{~b}$ & $34.8 \mathrm{a}$ & $37.2 \mathrm{~b}$ & $37.7 \mathrm{~b}$ & $36.0 \mathrm{a}$ & $37.1 \mathrm{a}$ \\
\hline Height $(\mathrm{cm})$ & $176.7 \mathrm{a}$ & $198.6 \mathrm{~b}$ & $178.5 \mathrm{a}$ & $188.4 \mathrm{~b}$ & $196.1 \mathrm{~b}$ & $186.3 \mathrm{a}$ & $189.0 \mathrm{a}$ \\
\hline Stem volume (cc) & $619.7 \mathrm{a}$ & $891.1 \mathrm{~b}$ & $651.1 \mathrm{a}$ & $791.4 \mathrm{~b}$ & $823.7 \mathrm{~b}$ & $725.2 \mathrm{a}$ & $785.6 \mathrm{a}$ \\
\hline Mortality (\%) & $7.6 \mathrm{a}$ & $6.6 \mathrm{a}$ & $4.2 \mathrm{a}$ & $7.9 \mathrm{ab}$ & $9.2 \mathrm{~b}$ & $6.3 \mathrm{a}$ & $7.9 \mathrm{a}$ \\
\hline
\end{tabular}

${ }^{1}$ Values in each row within a treatment factor (size, fertilization, vegetation control) that are followed by the same letter are not significantly different $(p \leq 0.05)$. Means were compared using the Fisher protected means comparison test. Means for a given treatment factor (size, fertilization, vegetation control) are pooled across the other two factors.

size class $(p=0.0117)$ and fertilization treatment $(p<0.0001)$, but not by weed control treatment $(p=0.5949)$. There was little difference in first-year mortality between the two size classes, but this difference increased with time. By year four, mortality had increased to $5.2 \%$ for the large seedlings and $8.9 \%$ for the small seedlings (Tab. II).

Mortality increased with the $1 \mathrm{~F}$ treatment only slightly in year one, but mortality increased with time. By year four, the greatest level of mortality occurred in the $2 \mathrm{~F}$ treatment $(11.1 \%)$, the $1 \mathrm{~F}$ treatment had a mean mortality of $6.3 \%$, while the NF treatment had $3.8 \%$ mortality rate.

\subsubsection{Seedling growth}

The difference in stem volume between the two diameter size classes increased greatly from $4.5 \mathrm{~cm}^{3}$ at planting to $268 \mathrm{~cm}^{3}$ by year four (Tab. II). The larger size class had significantly greater stem volume growth in all four years of the study. However, the percentage gain in stem volume due to planting larger stock decreased each year of the study. In year one, stem volume was $92 \%$ greater in the larger size class treatment than in the smaller, which decreased to a $35 \%$ gain by year four.

At planting, there was a 2.1-mm difference in basal diameter and a 13-cm difference in height between the larger and smaller size classes. By year four these differences increased to $4.4 \mathrm{~mm}$ and $26.5 \mathrm{~cm}$, respectively. No differences in height were found in year one or for diameter growth in years one or two among size class treatments (Tab. III). In year three, stem diameter growth was greater for the larger size $(10.1 \mathrm{~cm})$ than for the small size class $(9.1 \mathrm{~cm})$. In year four, this difference continued to increase, with the larger size class growing $12.3 \mathrm{~cm}$ and the smaller class growing $10.8 \mathrm{~cm}$. Similar increases occurred with height growth in years two through four.

The $1 \mathrm{~F}$ treatment increased fourth-year stem volume by $140 \mathrm{~cm}^{3}$ over the NF treatment (Tab. II). No differences in fourth-year stem volume between the $1 \mathrm{~F}$ and $2 \mathrm{~F}$ treatments were observed. Fertilization resulted in a yearly increase in stem volume growth for the first three years, but differences could no longer be identified by year four (Tab. III). The percentage of stem volume gain due to fertilization decreased more over time than did the gains from planting larger initial stock. Fertilization resulted in a $61 \%$ gain (data not shown) in stem volume after the first year, but this had dropped to nonsignificant ( $p=0.87$ ) 16\% by the fourth year (826.4 vs. 961.2).

Differences in diameter growth by fertilizer treatment were found only in year one, with fertilization increasing diameter growth by $3.35 \mathrm{~mm}$ (Tab. III). Yearly height growth was greater in the $1 \mathrm{~F}$ treatments in year one. No differences in height growth by fertilization treatment were observed in year two. The $2 \mathrm{~F}$ treatment resulted in greater height growth than either other treatment in year three, but did not differ in year four.

The third-year weed control treatment increased third-year stem volume an additional $153 \mathrm{~cm}^{3}$, a $12 \%$ gain (data not shown). This increased to an $18 \%$ gain by year four (Tab. II). The weed control treatment increased stem diameter growth in year three, which continued to increase into year four (Tab. III). However, height growth was not impacted in either year.

\subsubsection{Vegetation}

Vegetation cover percentage and height did not vary significantly by fertilizer treatment or initial stock size in any year of the study, or by weed control treatment in years one and two (Tab. IV). Vegetation cover averaged $26 \%$ with an average height of $25.9 \mathrm{~cm}$ across all treatments in year one. Cover and height increased to $50 \%$ and $50 \mathrm{~cm}$ in year two. The third-year vegetation control treatment significantly reduced cover percentage from $75 \%$ in the 2 -year treatment to $47 \%$ cover in the three-year treatment. Vegetation height also differed, being $81 \mathrm{~cm}$ in the two-year treatment and $73 \mathrm{~cm}$ in the three-year treatment. 
Table III. Mean diameter, height, and stem volume growth by treatment factor for each year of the study and by site.

\begin{tabular}{|c|c|c|c|c|c|c|c|}
\hline \multirow{2}{*}{ Year/treatment } & \multicolumn{2}{|c|}{ Size } & \multicolumn{3}{|c|}{ Fertilization } & \multicolumn{2}{|c|}{ Vegetation control } \\
\hline & Small & Large & $\mathrm{NF}$ & $1 \mathrm{~F}$ & $2 \mathrm{~F}$ & 2-years & 3 -years \\
\hline \multicolumn{8}{|l|}{ Orting site } \\
\hline \multicolumn{8}{|l|}{ Diameter (mm) } \\
\hline Year one & $3.0 \mathrm{a}^{1}$ & $3.1 \mathrm{a}$ & $1.8 \mathrm{a}$ & $3.7 \mathrm{~b}$ & $3.6 \mathrm{~b}$ & $3.0 \mathrm{a}$ & $3.0 \mathrm{a}$ \\
\hline Year two & $6.4 \mathrm{a}$ & $6.5 \mathrm{a}$ & $6.6 \mathrm{a}$ & $6.4 \mathrm{a}$ & $6.3 \mathrm{a}$ & $6.5 \mathrm{a}$ & $6.4 \mathrm{a}$ \\
\hline Year three & $9.1 \mathrm{a}$ & $10.1 \mathrm{~b}$ & $9.6 \mathrm{a}$ & $9.5 \mathrm{a}$ & $9.7 \mathrm{a}$ & $8.8 \mathrm{a}$ & $10.4 b$ \\
\hline Year four & $10.8 \mathrm{a}$ & $12.3 \mathrm{~b}$ & $11.8 \mathrm{a}$ & $11.6 \mathrm{a}$ & $11.3 \mathrm{a}$ & $10.8 \mathrm{a}$ & $12.3 b$ \\
\hline \multicolumn{8}{|l|}{ Height $(\mathrm{cm})$} \\
\hline Year one & $13.2 \mathrm{a}$ & $11.9 \mathrm{a}$ & $10.0 \mathrm{a}$ & $15.0 \mathrm{c}$ & $12.7 \mathrm{~b}$ & $12.4 \mathrm{a}$ & $12.7 \mathrm{a}$ \\
\hline Year two & $39.6 \mathrm{a}$ & $42.0 \mathrm{~b}$ & $43.0 \mathrm{a}$ & $39.2 \mathrm{a}$ & $40.2 \mathrm{a}$ & $40.1 \mathrm{a}$ & $41.5 \mathrm{a}$ \\
\hline Year three & $48.0 \mathrm{a}$ & $52.9 \mathrm{~b}$ & $47.5 \mathrm{a}$ & $52.0 \mathrm{~b}$ & $51.9 \mathrm{~b}$ & $50.5 \mathrm{a}$ & $50.4 \mathrm{a}$ \\
\hline Year four & $55.7 \mathrm{a}$ & $64.9 \mathrm{~b}$ & $60.0 \mathrm{a}$ & $61.0 \mathrm{a}$ & $59.85 \mathrm{a}$ & $58.6 \mathrm{a}$ & $62.0 \mathrm{a}$ \\
\hline \multicolumn{8}{|c|}{ Stem volume (cc) } \\
\hline Year one & $7.3 \mathrm{a}$ & $11.6 \mathrm{~b}$ & $5.1 \mathrm{a}$ & $12.4 \mathrm{~b}$ & $10.9 \mathrm{~b}$ & $9.4 \mathrm{a}$ & $9.6 \mathrm{a}$ \\
\hline Year two & $51.3 \mathrm{a}$ & $68.5 b$ & $52.2 \mathrm{a}$ & $63.6 b$ & $63.9 \mathrm{~b}$ & $60.0 \mathrm{a}$ & $59.8 \mathrm{a}$ \\
\hline Year three & $188.6 \mathrm{a}$ & $256.1 \mathrm{~b}$ & $195.1 \mathrm{a}$ & $233.3 b$ & $238.5 b$ & $205.1 \mathrm{a}$ & $239.5 \mathrm{a}$ \\
\hline Year four & $520.9 \mathrm{a}$ & $699.2 b$ & $565.3 \mathrm{a}$ & $645.5 \mathrm{a}$ & $619.3 \mathrm{a}$ & $549.7 \mathrm{a}$ & $670.4 \mathrm{~b}$ \\
\hline \multicolumn{8}{|l|}{ Belfair site } \\
\hline \multicolumn{8}{|l|}{ Diameter (mm) } \\
\hline Year one & $4.0 \mathrm{a}$ & $4.22 \mathrm{a}$ & $1.9 \mathrm{a}$ & $5.4 \mathrm{~b}$ & $5.1 b$ & $4.0 \mathrm{a}$ & $4.3 \mathrm{a}$ \\
\hline Year two & $7.3 \mathrm{a}$ & $7.87 \mathrm{a}$ & $7.6 a b$ & 7.1a & $8.1 b$ & $7.5 \mathrm{a}$ & $7.7 \mathrm{a}$ \\
\hline Year three & $10.2 \mathrm{a}$ & $11.1 \mathrm{a}$ & $10.8 \mathrm{a}$ & $10.6 \mathrm{a}$ & $10.7 \mathrm{a}$ & $10.0 \mathrm{a}$ & $11.3 b$ \\
\hline Year four & $8.1 \mathrm{a}$ & $8.9 \mathrm{a}$ & $8.7 \mathrm{a}$ & $8.7 \mathrm{a}$ & $8.1 \mathrm{a}$ & $8.8 \mathrm{a}$ & $8.2 \mathrm{a}$ \\
\hline \multicolumn{8}{|l|}{ Height (cm) } \\
\hline Year one & $9.3 \mathrm{a}$ & $10.7 \mathrm{~b}$ & $6.7 \mathrm{a}$ & $11.5 b$ & $11.8 \mathrm{~b}$ & $10.2 \mathrm{a}$ & $9.8 \mathrm{a}$ \\
\hline Year two & $33.6 \mathrm{a}$ & $31.8 \mathrm{a}$ & $31.2 \mathrm{a}$ & $31.7 \mathrm{a}$ & $35.3 \mathrm{~b}$ & $32.7 \mathrm{a}$ & $32.7 \mathrm{a}$ \\
\hline Year three & $42.7 \mathrm{a}$ & $48.3 b$ & $44.3 \mathrm{a}$ & $45.5 \mathrm{a}$ & $46.7 \mathrm{a}$ & $46.7 \mathrm{a}$ & $44.3 \mathrm{a}$ \\
\hline Year four & $54.0 \mathrm{a}$ & $60.9 b$ & $54.5 \mathrm{a}$ & $58.4 \mathrm{a}$ & $59.3 \mathrm{a}$ & $54.7 \mathrm{a}$ & $60.3 b$ \\
\hline \multicolumn{8}{|c|}{ Stem volume (cc) } \\
\hline Year one & $9.0 \mathrm{a}$ & $13.9 \mathrm{~b}$ & $4.3 \mathrm{a}$ & $15.2 \mathrm{~b}$ & $14.7 \mathrm{~b}$ & $11.1 \mathrm{a}$ & $11.8 \mathrm{a}$ \\
\hline Year two & $50.3 \mathrm{a}$ & $73.8 \mathrm{~b}$ & $46.9 \mathrm{a}$ & $63.4 \mathrm{~b}$ & $75.9 \mathrm{c}$ & $60.4 \mathrm{a}$ & $63.7 \mathrm{a}$ \\
\hline Year three & $189.2 \mathrm{a}$ & $269.4 b$ & $194.8 \mathrm{a}$ & $232.5 \mathrm{ab}$ & $260.5 b$ & $215.3 \mathrm{a}$ & $243.2 \mathrm{a}$ \\
\hline Year four & $368.8 \mathrm{a}$ & $528.1 \mathrm{~b}$ & $400.4 a$ & $481.5 \mathrm{a}$ & $463.5 \mathrm{a}$ & $435.2 \mathrm{a}$ & $461.7 \mathrm{a}$ \\
\hline
\end{tabular}

${ }_{1}^{1}$ Values in each row within a treatment factor (size, fertilization, vegetation control) that are followed by the same letter are not significantly different $(p \leq 0.05)$. Means were compared using the Fisher protected means comparison test. Means for a given treatment factor (size, fertilization, vegetation control) are pooled across the other two factors.

Differences in cover and height were still present into year four with the two-year treatment having greater cover (68\%) than the three-year treatment $(56 \%)$. Vegetation height showed the opposite response, with the tallest vegetation found in the three-year treatment vs. the two-year treatment $(121 \mathrm{~cm}$ and $92 \mathrm{~cm}$, respectively).

The most predominant competitive species across the site changed through the four years of the study and after year three, the predominant species varied by vegetation control treatment. In year one, brackenfern, bedstraw (Galium aparine L.), and swordfern were the most predominant species (Tab. IV). In year two the site was largely dominated by herbaceous species including woodland goundsel (Senecio sylvaticus L.), false dandelion (Hypochaeris radicata L.), and fireweed (Epilobium angustifolium L.). By year three, false dandelion was the most predominant species in the two-year 
Table IV. Mean vegetation cover and height in each year of the study at both experimental sites by vegetation-control treatment. Mean frequency of the dominant species on a per-plot basis by vegetationcontrol treatment.

\begin{tabular}{l} 
Site \\
\hline Orting 2-year vegetation-control treatment \\
Vegetation cover (\%) \\
Vegetation height (cm) \\
Mean frequency species was the dominant \\
cover in a plot \\
Hypochaeris radicata \\
Epilobium angustifolium \\
Pteridium aquifolium \\
Sambucus racemosa \\
Polysticum munitum \\
Galium aparine \\
Dicentra formosa \\
Senicio sylvaticus
\end{tabular}

No cover

Orting 3-year vegetation-control treatment

\begin{tabular}{|c|c|c|c|c|}
\hline Vegetation cover (\%) & 25.6 & 51.1 & 46.7 & 56 \\
\hline Vegetation height $(\mathrm{cm})$ & 27.2 & 51.3 & 73.3 & 121 \\
\hline \multicolumn{5}{|c|}{$\begin{array}{l}\text { Mean frequency species was the dominant } \\
\text { cover in a plot }\end{array}$} \\
\hline Hypochaeris radicata & 1.3 & 9.1 & 6.1 & 6.6 \\
\hline Epilobium angustifolium & 10.6 & 17.8 & 54.9 & 52.1 \\
\hline Pteridium aqualinum & 15.5 & 4.1 & 5.1 & 7.9 \\
\hline Sambucus racemosa & 8.5 & 6.3 & 17.2 & 20.7 \\
\hline Polystichum munitum & 14.1 & 1 & 0 & 0.1 \\
\hline Galium aparine & 17.9 & 5.3 & 0.2 & 0 \\
\hline Dicentra formosa & 2.3 & 1.4 & 0 & 0 \\
\hline Senicio sylvaticus & 0.7 & 21.1 & 0 & 0 \\
\hline No cover & 4.3 & 0 & 5.7 & 2.3 \\
\hline \multicolumn{5}{|c|}{ Belfair 2-year vegetation-control treatment } \\
\hline Vegetation cover $(\%)$ & 8.3 & 25.3 & 53.7 & 39.9 \\
\hline Vegetation height (cm) & 16.8 & 39.4 & 67.8 & 57.3 \\
\hline \multicolumn{5}{|c|}{$\begin{array}{l}\text { Mean frequency species was the dominant } \\
\text { cover in a plot }\end{array}$} \\
\hline Pteriduim aquifolium & 21.3 & 66 & 68 & 73 \\
\hline Galtheria shallon & 44.8 & 13.7 & 8.6 & 6.3 \\
\hline Vacinium ovatum & 12.2 & 1.4 & 0.5 & 0.46 \\
\hline Epliobium angustifolium & 0.37 & 3.6 & 5.1 & 4.8 \\
\hline Senecio sylvaticus & 0.01 & 0.7 & 5.6 & 0.01 \\
\hline Rubus ursinus & 1.2 & 0.7 & 0.9 & 0.4 \\
\hline No cover & 15.7 & 9.1 & 6.2 & 2.3 \\
\hline
\end{tabular}

Table IV. Continued.

Belfair 3-year vegetation-control treatment

$\begin{array}{lcccc}\text { Vegetation cover }(\%) & 8 & 24 & 39 & 39.6 \\ \text { Vegetation height (cm) } & 16.8 & 37.1 & 51.4 & 59.6 \\ \begin{array}{l}\text { Mean frequency species was the dominant } \\ \text { cover in a plot }\end{array} & & & & \\ \quad \text { Pteriduim aquifolium } & 18 & 55 & 54 & 60 \\ \quad \text { Galtheria shallon } & 43 & 16.8 & 18.6 & 11 \\ \quad \text { Vaccinium ovatum } & 17 & 8.7 & 1.2 & 1.8 \\ \quad \text { Epliobium angustifolium } & 0.5 & 8.5 & 11.3 & 12.4 \\ \quad \text { Senecio sylvaticus } & 0.4 & 0.9 & 0.4 & 0.4 \\ \quad \text { Rubus ursinus } & 1.6 & 1.9 & 0.5 & 0.3 \\ \text { No cover } & 14.8 & 8.7 & 8.3 & 3.5 \\ \text { ANOVA contrast "2-year vs. 3 year" } & p \text {-value } & p \text {-value } & p \text {-value } & p \text {-value }\end{array}$

Orting

\begin{tabular}{lcccc} 
Vegetation cover percentage & 0.805 & 0.481 & 0.0001 & 0.0001 \\
Vegetation height & 0.175 & 0.797 & 0.031 & 0.0001 \\
Belfair & & & & \\
$\quad$ Vegetation cover percentage & 0.836 & 0.631 & 0.0001 & 0.881 \\
Vegetation height & 0.991 & 0.493 & 0.168 & 0.532 \\
\hline
\end{tabular}

vegetation control treatment and stayed the dominant into year four. The three-year vegetation control treatment greatly reduced the dominance of false dandelion and increased the importance of fireweed and elderberry (Sambucus racemosa L.), a trend that continued into year four.

\subsubsection{Needle nutrients}

Nutrients were measured during years one and two prior to the third-year weed control treatment. For this reason, differences due to weed control would not be expected and were not found for any nutrient sampled. No differences in nutrient concentration between the seedling size classes occurred in either year one or two (Tab. V). The fertilization treatments resulted in an increase in first-year $\mathrm{N}$ and $\mathrm{B}$ concentrations and decreases in $\mathrm{P}$ and $\mathrm{K}$ concentrations. No other nutrient concentration varied by fertilizer treatment in year one.

Foliage concentrations of N, P, K, Ca, S, Mg, and B dropped considerably from year one to two regardless of treatment (Tab. V). Most notable among these was $\mathrm{N}$, which dropped from a first-year range of $1.85 \%-2.07 \%$ to $1.42 \%-1.52 \%$ in the second year. Concentrations of the remainder of nutrients tended to either stay the same or increase. Needle weight in year two was less in the fertilized treatments than in the NF treatments, but did not differ between the $1 \mathrm{~F}$ and $2 \mathrm{~F}$ treatments. Boron and $\mathrm{Fe}$ concentrations were greater in the fertilized treatments, while $\mathrm{Ca}$ was less. Among fertilized treatments, $\mathrm{B}$ concentration was greater in $2 \mathrm{~F}$ treatment than the $1 \mathrm{~F}$ treatment. Concentration of $\mathrm{K}$ was greater in the $1 \mathrm{~F}$ treatment than the $2 \mathrm{~F}$, but neither differed from the NF treatment. 
Table V. Means of foliar nutrient concentrations for the Orting site by fertilizer treatment, and caliper size-class treatments. Results of statistical contrasts from the ANOVA procedure. Values in bold are significant at $p<0.05$.

\begin{tabular}{|c|c|c|c|c|c|c|c|c|c|c|c|c|}
\hline Year 1 & $\begin{array}{l}\text { Needle } \\
\text { weight }\end{array}$ & $\mathrm{N} \%$ & $\mathrm{P} \%$ & $\mathrm{~K} \%$ & $\mathrm{Ca} \%$ & $\mathrm{~S} \%$ & $\mathrm{Mg} \%$ & $\begin{array}{c}\mathrm{Cu} \\
\mathrm{mg} \mathrm{kg}^{-1}\end{array}$ & $\begin{array}{c}\mathrm{Fe} \\
\mathrm{mg} \mathrm{kg}^{-1}\end{array}$ & $\begin{array}{c}\mathrm{Zn} \\
\mathrm{mg} \mathrm{kg}^{-1}\end{array}$ & $\begin{array}{c}\mathrm{Mn} \\
\mathrm{mg} \mathrm{kg}^{-1}\end{array}$ & $\begin{array}{c}\mathrm{B} \\
\mathrm{mg} \mathrm{kg}^{-1}\end{array}$ \\
\hline \multicolumn{13}{|l|}{ Fertilization treatment } \\
\hline No fertilizer & 0.3531 & 1.82 & 0.1951 & 0.7155 & 0.371 & 0.1682 & 0.1004 & 3.4 & 47.2 & 27.3 & 330 & 30.96 \\
\hline 1-year fertilizer & 0.3681 & 2.01 & 0.1801 & 0.6365 & 0.345 & 0.1659 & 0.098 & 3.16 & 42.9 & 26.1 & 320 & 50.02 \\
\hline 2-years fertilizer & 0.4 & 2.07 & 0.156 & 0.6094 & 0.344 & 0.1671 & 0.104 & 3 & 42.6 & 23.1 & 276 & 57.2 \\
\hline \multicolumn{13}{|l|}{ Caliper size-class treatment } \\
\hline Small & 0.3946 & 1.99 & 0.18 & 0.6689 & 0.3729 & 0.172 & 0.1005 & 3.32 & 45.4 & 28.1 & 329 & 46.2 \\
\hline Large & 0.3529 & 1.94 & 0.17 & 0.6386 & 0.3341 & 0.1622 & 0.1015 & 3.05 & 43 & 22.9 & 289 & 45.9 \\
\hline Contrast "large vs. small" & 0.0648 & 0.46 & 0.3675 & 0.2008 & 0.0528 & 0.1967 & 0.7878 & 0.1247 & 0.3106 & 0.006 & 0.0572 & 0.9359 \\
\hline Contrast "no fertilizer vs. fertilizer" & 0.1888 & 0.0016 & 0.0002 & 0.0007 & 0.213 & 0.837 & 0.8305 & 0.088 & 0.0831 & 0.1602 & 0.1433 & 0.0001 \\
\hline Contrast " 1 year vs. 2 years" & 0.2398 & 0.4516 & 0.0032 & 0.3475 & 0.9742 & 0.893 & 0.2863 & 0.4469 & 0.9152 & 0.1799 & 0.0834 & 0.1517 \\
\hline
\end{tabular}

Year 2

Fertilization treatment

\begin{tabular}{lcccccccccccc} 
No fertilizer & 1.17 & 1.42 & 0.1306 & 0.525 & 0.35 & 0.1319 & 0.0912 & 7.31 & 76.3 & 32.2 & 332 & 14.61 \\
1-year fertilizer & 0.98 & 1.46 & 0.1419 & 0.5688 & 0.304 & 0.1344 & 0.085 & 7.25 & 88.9 & 32.1 & 422 & 18.6 \\
$\begin{array}{l}\text { 2-years fertilizer } \\
\text { aliper size-class treatment }\end{array}$ & 0.97 & 1.52 & 0.1425 & 0.5188 & 0.299 & 0.1325 & 0.086 & 7.37 & 85.6 & 30.9 & 441 & 21.6 \\
Small & & & & & & & & & & & \\
Large & 1.018 & 1.47 & 0.138 & 0.5458 & 0.3354 & 0.1325 & 0.0879 & 7.25 & 82.2 & 34.5 & 441 & 18.38 \\
ontrast "large vs. small" & 1.067 & 1.47 & 0.139 & 0.5292 & 0.3 & 0.1333 & 0.087 & 7.38 & 85 & 28.9 & 343 & 18.15 \\
ontrast "no fertilizer vs. fertilizer" & 0.1565 & 0.9422 & 0.916 & 0.2959 & 0.0649 & 0.8102 & 0.8293 & 0.6333 & 0.3708 & 0.012 & 0.0518 & 0.8408 \\
ontrast "1 year vs. 2 years" & 0.7291 & 0.2638 & 0.9485 & $\mathbf{0 . 0 1 3 8}$ & 0.8485 & 0.6594 & 0.7917 & 0.6967 & 0.3769 & 0.6523 & 0.9843 & $\mathbf{0 . 0 4 2 8}$ \\
\hline
\end{tabular}

\subsection{Belfair}

\subsubsection{Seedling mortality}

Seedling mortality averaged less than $5 \%$ for all treatments after one growing season. Mortality increased slightly over the first four years, but by year four it still averaged less than $10 \%$ across all the study factor levels (Tab. II). Of the three factors evaluated (initial stock size, vegetation control, and fertilization), only the fertilization treatment had a significant impact on seedling mortality $(p=0.05)$. Plots that were fertilized had $2 \%$ more mortality than unfertilized plots after the first year. By year four, this had increased to a $4 \%-5 \%$ difference. No statistical differences were found between the $1 \mathrm{~F}$ and $2 \mathrm{~F}$ fertilization treatments.

\subsubsection{Seedling growth}

Similar to the Orting site, the difference in stem volume between the two size classes increased from planting through year four, from $3.6 \mathrm{~cm}^{3}$ (data not shown) to $272 \mathrm{~cm}^{3}$ (Tab. II). The larger size class had significantly greater stem volume growth in all four years of the study (Tab. III). Like Orting, the percentage gain in stem volume from planting larger stock dropped each year of the study. At planting, the larger size class seedlings had stem volumes $164 \%$ greater than the small class. By year four, this percentage difference had dropped, with the larger size class now $43 \%$ greater than the smaller (619.7 vs. 891.1).

At planting there was a 2.2-mm difference in basal diameter and a 9-cm difference in height between the larger and smaller size classes. These differences increased to $4.8 \mathrm{~mm}$ and $21.9 \mathrm{~cm}$, respectively, by year four (Tab. II). However, differences in stem diameter growth were not significant in any one year (Tab. III). Height growth was greater for the larger size class every year except year two.

The $1 \mathrm{~F}$ treatment resulted in an increase in fourth-year volume of $140 \mathrm{~cm}^{3}$ over the NF treatment, while the $1 \mathrm{~F}$ and $2 \mathrm{~F}$ treatment did not differ (Tab. III). Differences in volume growth were observed between the NF and $1 \mathrm{~F}$ treatment each year of the study except year four. The $2 \mathrm{~F}$ treatment had greater volume growth than both the NF and $1 \mathrm{~F}$ treatment in year two. The $2 \mathrm{~F}$ treatment also had greater volume growth than the NF treatment in year three but did not differ in year four. The $1 \mathrm{~F}$ treatment resulted in $125 \%$ (data not shown) increase in volume in year one, which decreased to a gain of $22 \%$ by year four (651.1 vs. 791.4). 
Table VI. Means of foliar nutrient concentrations for the Belfair site by fertilizer treatment, and caliper size class treatments. Results of statistical contrasts from the ANOVA procedure. Values in bold are significant at $p<0.05$.

\begin{tabular}{|c|c|c|c|c|c|c|c|c|c|c|c|c|}
\hline Year 1 & $\begin{array}{l}\text { Needle } \\
\text { weight }\end{array}$ & $\mathrm{N} \%$ & $\mathrm{P} \%$ & $\mathrm{~K} \%$ & $\mathrm{Ca} \%$ & $\mathrm{~S} \%$ & $\mathrm{Mg} \%$ & $\begin{array}{c}\mathrm{Cu} \\
\mathrm{mg} \mathrm{kg}^{-1}\end{array}$ & $\begin{array}{c}\mathrm{Fe} \\
\mathrm{mg} \mathrm{kg}^{-1}\end{array}$ & $\underset{\mathrm{Zn}}{\mathrm{mg} \mathrm{kg}^{-1}}$ & $\underset{\mathrm{Mn}}{\mathrm{Mn} \mathrm{kg}}$ & $\begin{array}{c}\text { B } \\
\mathrm{mg} \mathrm{kg}^{-1}\end{array}$ \\
\hline \multicolumn{13}{|l|}{ Fertilization treatment } \\
\hline No fertilizer & 0.36 & 2.05 & 0.285 & 0.615 & 0.373 & 0.164 & 0.099 & 3.33 & 46.3 & 38.8 & 457 & 16.3 \\
\hline 1-year fertilizer & 0.47 & 2.66 & 0.18 & 0.528 & 0.379 & 0.178 & 0.093 & 2.55 & 40.82 & 19.5 & 330 & 45.7 \\
\hline 2-years fertilizer & 0.43 & 2.62 & 0.173 & 0.519 & 0.407 & 0.177 & 0.098 & 2.38 & 38.65 & 15.9 & 298 & 45.7 \\
\hline \multicolumn{13}{|l|}{ Caliper size-class treatment } \\
\hline Small & 0.431 & 2.475 & 0.216 & 0.565 & 0.409 & 0.183 & 0.089 & 2.76 & 40 & 27.57 & 402 & 35.4 \\
\hline Large & 0.406 & 2.2 & 0.209 & 0.543 & 0.364 & 0.165 & 0.104 & 2.73 & 43.34 & 21.88 & 321 & 36.5 \\
\hline Contrast "large vs. small" & 0.1577 & 0.353 & 0.387 & 0.0918 & 0.0038 & 0.0003 & 0.0004 & 0.7316 & 0.0855 & 0.0014 & 0.0246 & 0.8146 \\
\hline Contrast "no fertilizer vs. fertilizer" & 0.0001 & 0.0001 & 0.0001 & 0.0001 & 0.2207 & 0.0046 & 0.318 & 0.0001 & 0.0011 & 0.0001 & 0.0004 & 0.0001 \\
\hline Contrast "1 year vs. 2 years" & 0.0489 & 0.6108 & 0.4777 & 0.5896 & 0.1318 & 0.8446 & 0.283 & 0.2227 & 0.5585 & 0.089 & 0.4508 & 0.9945 \\
\hline
\end{tabular}

Year 2

Fertilization treatment

\begin{tabular}{lcccccccccccc} 
No fertilizer & 1.05 & 1.49 & 0.1855 & 0.5 & 0.355 & 0.1295 & 0.1025 & 8.25 & 143.45 & 34.45 & 366.8 & 7.97 \\
$\quad$ 1-year fertilizer & 0.915 & 1.39 & 0.1645 & 0.475 & 0.308 & 0.1235 & 0.095 & 7.9 & 162.85 & 29.6 & 425.95 & 9.6 \\
$\quad \begin{array}{l}\text { 2-years fertilizer } \\
\text { Caliper size-class treatment }\end{array}$ & 0.972 & 1.5 & 0.1365 & 0.47 & 0.308 & 0.112 & 0.0945 & 7.4 & 162.1 & 28.45 & 501.8 & 16.2 \\
$\quad$ Small & & & & & & & & & & & & \\
$\quad$ Large & 0.945 & 1.48 & 0.163 & 0.4767 & 0.3287 & 0.122 & 0.096 & 7.93 & 153.93 & 32.7 & 448.9 & 10.93 \\
Contrast "large vs. small" & 1.0163 & 1.44 & 0.158 & 0.4867 & 0.314 & 0.1213 & 0.099 & 7.76 & 158.33 & 28.9 & 414.2 & 11.57 \\
Contrast "no fertilizer vs. fertilizer" & 0.182 & 0.6098 & 0.2541 & 0.5927 & 0.2616 & 0.9074 & 0.3769 & 0.5474 & 0.6919 & $\mathbf{0 . 0 2 6 6}$ & 0.3238 & 0.6696 \\
Contrast "1 year vs. 2 years" & 0.3811 & 0.1039 & $\mathbf{0 . 0 0 2 8}$ & 0.8269 & 0.6598 & 0.1064 & 0.9134 & 0.1446 & 0.956 & 0.5537 & 0.0815 & $\mathbf{0 . 0 0 0 7}$ \\
\hline
\end{tabular}

Diameter growth was greater in the $1 \mathrm{~F}$ treatment $(5.4 \mathrm{~mm})$ than in the NF treatment $(1.9 \mathrm{~mm})$ in year one (Tab. III). In year two, the $2 \mathrm{~F}$ treatment had greater diameter growth than the $1 \mathrm{~F}$, but not the NF treatments, which did not differ. No differences in diameter growth were observed in years three or four. A similar pattern of yearly growth response was observed for height.

The third-year weed-control treatment had no observable effect on fourth-year stem volume or on volume growth in years three or four. The weed-control treatment increased third-year diameter growth slightly $(1.3 \mathrm{~mm})$, but no increases in third-year height growth were found. However, a $5.6 \mathrm{~cm}$ gain in height was observed in year four.

\subsubsection{Vegetation}

Vegetation cover percentage and height did not vary significantly by fertilizer treatment or diameter size class in any year of the study, or by vegetation control treatment in years one and two. Vegetation cover averaged $8.17 \%$ across all treatments in year one. Cover increased to $24.6 \%$ in year two and did not differ by any of the treatment factors (Tab. IV). The three-year weed control treatment significantly reduced cover percentage from $53.6 \%$ in the two-year treatment to $39.0 \%$ cover in the three-year treatment. Vegetation height was reduced from $68 \mathrm{~cm}$ in the two-year to $51 \mathrm{~cm}$ in the three-year vegetation-control treatment. By year four, no differences in cover or height were observed between the vegetation control treatments; cover and height averaged $40 \%$ and $58 \mathrm{~cm}$, respectively, across all treatments.

The most predominant species in all four years of the study were salal, bracken fern, evergreen huckleberry, fireweed, and trailing blackberry (Rubus ursinus Cham. \& Schlecht.) (Tab. IV). Bracken fern was by far the most frequent competitor on the site in all but the first year. The three-year vegetation control treatment tended to slightly increase the predominance of fireweed and salal, compared with the two-year vegetation control treatment.

\subsubsection{Nutrients}

In year one, differences in nutrient concentrations between the size class treatments existed for $\mathrm{Ca}, \mathrm{S}, \mathrm{Mg}, \mathrm{Zn}$, and $\mathrm{Mn}$ (Tab. VI). Of these, concentrations were lower in the large stock size compared with the smaller size for all but $\mathrm{Mg}$. The $1 \mathrm{~F}$ treatments impacted nutrient concentrations of all nutrients sampled except $\mathrm{Ca}$ and $\mathrm{Mg}$. Fertilization resulted in an increase of $\mathrm{N}, \mathrm{S}$, and $\mathrm{B}$ and a decrease in concentration of $\mathrm{P}$, 
$\mathrm{K}, \mathrm{Cu}, \mathrm{Fe}, \mathrm{Zn}$, and $\mathrm{Mn}$. Fertilization also increased needle weight in year one.

Foliage concentrations of $\mathrm{N}, \mathrm{P}, \mathrm{K}, \mathrm{Ca}, \mathrm{S}$, and B dropped considerably in year two from levels measured in year one, regardless of treatment (Tab. VI). Most notable among these changes was $\mathrm{N}$, which dropped from a first year range of $2.05 \%$ to $2.62 \%$, down to $1.39 \%$ to $1.5 \%$ in year two. Boron also dropped from a high of $45.7 \mathrm{ppm}$ in the fertilized treatments in year one to a high of $16.2 \mathrm{ppm}$ in year two. Concentrations of the remainder of nutrients tended to either stay the same or increase, with some - such as $\mathrm{Cu}$ and $\mathrm{Fe}$ - doubling or tripling in concentration in measurement year two. Zinc concentrations continued to be less in the smaller caliper size class than in the larger size class in year two, although this difference was small. The fertilizer treatments resulted in an increase in foliar concentrations of $\mathrm{B}$ and $\mathrm{Mn}$ and a decrease in $\mathrm{P}, \mathrm{Ca}, \mathrm{Cu}$, and $\mathrm{Zn}$, compared with the NF treatment. Differences between the $1 \mathrm{~F}$ and $2 \mathrm{~F}$ treatments were found for only $\mathrm{B}$ and $\mathrm{P}$. Boron concentration was increased, while $\mathrm{P}$ decreased. Needle weights were marginally $(p=0.055)$ affected by the $2 \mathrm{~F}$ treatment, with needle weight tending to be smaller in the fertilized than in the NF treatments.

\section{DISCUSSION}

\subsection{Interaction of treatments}

South et al. [34] proposed several potential interactive response patterns among nursery and site-preparation treatments. Among these was a non-interactive or additive response. Our results mirrored this additive response pattern, with no treatment interacting with any other. In other words, gains from planting larger stock were additive to gains from fertilizing or applying an additional third year of weed control. However, there were large differences in the magnitude of response to different treatments.

There are few examples in the reforestation literature that evaluate the interactive effects of planting different sized seedlings and either weed control or fertilization for conifers. Only one study was found that evaluated the interaction of all three factors: stock size, fertilization, and weed control [33]. This showed that gains in mid-rotation (12-year) loblolly pine resulting from planting larger stock were additive to those from either fertilization or weed control. However, in their study, fertilization and weed control interacted such that without weed control there were no fertilizer responses. In studies wherein the interactions between seedling size at planting and weed control were examined, the responses have been additive $[13,17,31,32]$. We are aware of only two published reports that compare planting different sized Douglas-fir seedlings that received similar nursery cultural histories in combination with fertilization treatments. Strothmann [35] found that threeyear height growth gains were additive to those from fertilization with Agriform ${ }^{\circledR}$ tablets on a granitic soil in northern California. Rose et al. [25] found no response to fertilization with Agriform fertilizer pellets regardless of seedling size at planting.

The interactive effects of weed control and fertilization on Douglas-fir growth tend to be less consistent than with initial stock size. Our results support those of Rose and Ketchum [23], who reported additive responses to weed control and fer- tilization at those sites where a fertilizer response was found. This was in contrast to Roth and Newton [29], who found that broadcast urea fertilization resulted in a decrease in survival and growth if no weed control was applied, and no positive responses to fertilization in the presence of weed control. Their results closely mirrored those of White and Newton [44], with a negative response to fertilization in the absence of weed control. It should be noted that in both of the latter two studies, broadcast applications of fertilizer were used. In contrast, Austin and Strand [2] reported a positive growth response to urea-formaldehyde and triple-super phosphate fertilization only when weed control was applied; they added fertilizer to the hole at planting. Similar interactive effects have been identified in other forest environments [12, 33, 36, 39].

Several factors play a role in generating a positive response to early fertilization, including placement, rate, and formulation [3]. The environment of the plantation site must also have adequate growing season soil moisture [15]. This is illustrated nicely by a study that evaluated ponderosa pine growth to weed control and fertilization treatments [21]. They found their best fertilizer responses on moist sites. On drier sites, seedling responses to fertilizers were less relative to weed control and only occurred if weed control was applied. It is likely the two years of weed control applied in our study provided an environment favorable to an additive fertilizer and weed control response.

In Sweden Nilsson and Orlander [18] studied the response of newly planted Norway spruce seedlings to fertilization, irrigation and herbicide treatments. Their results showed that stem volume was positively affected by herbicide treatment (H) and by fertilization in combination with herbicide treatment $(\mathrm{FH})$, whereas seedling growth was not affected by fertilization only. By the end of the third growing season the stem volume $\left(\mathrm{cm}^{3}\right)$ for the fertilization and herbicide combination was 106.8 versus 29.2 for the control. The $\mathrm{FH}$ treatment proved to be a $365 \%$ improvement!

\subsection{Seedling size response}

Planting seedlings $2 \mathrm{~mm}$ larger had a greater impact on fourth-year stem volume than either early fertilization or a third year of weed control. The $2 \mathrm{~mm}$ difference in stem diameter at planting resulted in a $35 \%$ (775.2 vs. 1043.2) increase in fourth-year stem volume at the Orting site and a 43\% (619.7 vs. 891.1) increase at the Belfair site. The benefit derived from planting larger stock was consistent with other published studies for Douglas-fir [11, 27, 35]. Similar trends have also been reported for other conifer species in dramatically different environments [17, 31-33].

The duration over time in which differences in initial stem diameter will still be identifiable is unknown. Results from other authors suggest that planting larger stock will produce measurable differences for several years to come [27]. Rose et al. [27] was still able to identify significant differences in stem volume eight years after planting seedlings with larger root volumes. Although root volume was the grading criterion in their study, stem diameter was also larger in the largest root volume class [27]. Differences due to using loblolly pine seedlings only $1 \mathrm{~mm}$ larger at planting were still identifiable 12 years later [33]. 


\subsection{Third year weed control response}

The third-year weed control treatment had an effect at the Orting site, but not the Belfair site. The lack of response at Belfair is largely attributed to poor efficacy of the third-year herbicide treatment. The predominant competitive species at Belfair (bracken fern, salal, and evergreen huckleberry) proved to be resistant to the Velpar-Oust mixture applied. Both of these herbicides tend to be more effective on germinating forbs and grasses, of which there were few at Belfair. In contrast, the Orting site was rich in grasses and forbs early in the season and the third-year weed control treatment provided a weed-free window that elicited a positive tree growth response. However, by mid-July, when the vegetation surveys were performed, cover was not greatly different between the weed-control treatments. This was due to an expansion of fireweed and elderberry cover. Neither species was much affected by the herbicide treatment, but instead were released from competition similar to the Douglas-fir. Regardless, the third-year weed control treatment resulted in an $18 \%$ increase (832.8 vs. 985.5) in stem volume at year four, roughly half that achieved with planting larger stock.

Weed control over the first few years of plantation establishment will result in marked increases in seedling growth $[14,28]$. The impact of first-year weed control relative to second- or third-year weed control treatments on Douglas-fir is less understood. Fifth-year Douglas-fir stem volume was increased by $82 \%, 115 \%$, and $217 \%$ for one, two and three years of weed control in the central coast range of Oregon [16]. We are unaware of any other studies in which similar treatment regimes for Douglas-fir were examined, with the exception of O'Dea [19]; in that study, deer browse confounding made it difficult to draw conclusions. Wagner et al. [43] demonstrated differences in conifer response to multiple years of weed control. They found that white pine responds to each additional year of weed control, up to five years, in a near-linear fashion, while Jack and red pine no longer responded after the first two years, and black spruce stopped responding after three years. Our results suggest that on sites where herbaceous species are still present into year three, weed control can continue to elicit a growth response. The ultimate long-term benefit of a third year of weed control has not yet been determined.

\subsection{Fertilization response}

Early gains from fertilization could no longer be identified at the Orting site in year four and the difference between fertilized and NF treatments at Belfair had decreased. These results support those of Rose and Ketchum [23], who found that initial gains from IBDU (isobutylidene diurea) fertilization was largely restricted to the first two years of growth. Our results contrast with others who have reported an increasing response to fertilization over the first three to seven years of growth [5, 40]. Fertilization resulted in roughly a $2-\mathrm{mm}$ gain in stem diameter in year one at Orting. This gain was easily identified as significant in the first couple years of the study. However by year four, variability in stem diameter increased due to several other microsite factors, and even though a 2-mm gain was still evident in the means of the fertilized and NF seedlings, statistical differences were no longer identifiable. At Belfair, the gain was slightly larger and was still significant into year four, but may not be identifiable in future years, as the trees continue to get larger.

The second-year fertilizer treatment was marginally effective at only one of the two sites. This treatment was dibbled to the side of the seedling, which may explain its lack of effectiveness. Dibbling fertilizer only provides added nutrition to a portion of the rooting zone of a seedling. If no roots are located within this zone the potential to have a positive effect is limited. Others have also demonstrated that dibbled fertilization is less effective at eliciting a growth response than is adding fertilizer to the hole at planting $[4,5]$.

Foliage nutrient concentrations suggest that most of the gains from fertilization resulted from increasing the availability of $\mathrm{N}$ over most other nutrients. Concentrations of $\mathrm{P}$ and $\mathrm{K}$ dropped, suggesting that both were diluted by the enhanced $\mathrm{N}$-induced growth. Another controlled-release fertilizer, manufactured by J.R. Simplot \& Co. and incorporating a different coating, releases $\mathrm{P}$ and $\mathrm{K}$ at much slower rates than $\mathrm{N}$ [1]. Although the coatings are different both the Simplot and Scott's products rely on osmotic diffusion to deliver nutrients. The rate of $\mathrm{P}$ and $\mathrm{K}$ release from the Scott's controlled release prills may also not be as fast as for nitrogen, although this has not been tested directly. If this is the case, it might be possible to enhance early growth gains by using slightly different fertilizer blends and release technologies.

\section{CONCLUSION}

Reforestation managers in the Coastal zone of the Pacific Northwest commonly plant a seedling with a basal caliper ranging from 4 to $6 \mathrm{~mm}$ and apply one to two years of herbaceous weed control. Our results suggest that the best option for increasing early growth is to plant larger diameter seedlings. Although the fertilization treatments we used produced early gains, they were short lived. Further research is needed to better understand the fate and amount of fertilizers in the forest environment (i.e., nutrient leaching, $\mathrm{P}$ fixation, uptake by weeds, insoluble compounds) along with understanding how fertilizers may be applied in ways that produce greater longterm gains. The third-year weed control treatments produced modest gains in stem volume at the Orting site where herbaceous competition was present. The success of third-year weed-control treatments generally will depend on the presence of weed competition and the site-specific effectiveness of the herbicides used.

\section{REFERENCES}

[1] Alzugaray P., Effects of fertilization at the time of planting on field performance of $1+1$ Douglas-fir seedlings, M.S. thesis, Forest Science Department, Oregon State University, Corvallis, 2002.

[2] Austin R.C., Strand R.F., The use of slowly soluble fertilizers in forest planting in the Pacific Northwest, J. For. 58 (1960) 618-627.

[3] Brockley R.P., The effects of fertilization on the early growth of planted seedlings: a problem approach, Can. For. Serv., Br. Columbia Minist. of For., Res. Branch, FRDA Rep. 011, 1988, 22 p. 
[4] Carlson W.C., Effects of controlled-release fertilizers on shoot and root development of outplanted western hemlock (Tsuga heterophylla Rag. Sarg.) seedlings, Can. J. For. Res. 11 (1981) 752-757.

[5] Carlson W.C., Preisig C.L., Effects of controlled-release fertilizers on the shoot and root development of Douglas-fir seedlings, Can. J. For. Res. 11 (1981) 230-242.

[6] Cole C., Newton M., Fifth-year responses of Douglas-fir to crowding and nonconiferous competition, Can. J. For. Res. 17 (1987) 181-186.

[7] Crouch G.L., Radwan M.A., Effects of nitrogen and phosphorus fertilizers on deer browsing and growth of young Douglas-fir, USDA For. Serv., Pac. Northw. Res. Exp. Stn., Res. Note 368, 1981, $15 \mathrm{p}$.

[8] Haase D.L., Rose R., Soil moisture stress induces transplant shock in stored and unstored 2+0 Douglas-fir seedlings of varying root volumes, For. Sci. 39 (1993) 275-294.

[9] Haase D.L., Rose R., Effects of soil water content and initial root volume on the nutrient status of $2+0$ Douglas-fir seedlings, New For. 8 (1994) 265-277.

[10] Harrington T.B., Wagner R.G., Radosevich S.R., Walstad J.D., Interspecific competition and herbicide injury influence 10-year responses of coastal Douglas-fir and associated vegetation to release treatments, For. Ecol. Manage. 76 (1995) 55-67.

[11] Long A.J., Carrier B.D., Effects of Douglas-fir 2+0 seedling morphology on field performance, New For. 7 (1993) 19-32.

[12] Mason E.G., Milne P.G., Effects of weed control, fertilization, and soil cultivation on the growth of Pinus radiata at midrotation in Canterbury, New Zealand, Can. J. For. Res. 29 (1999) 985-992.

[13] Mitchell R.J., Zutter B.R., South D.B., Interaction between weed control and loblolly pine, Pinus taeda, seedling quality, Weed Technol. 2 (1988) 191-195.

[14] Monleon V.J., Newton M., Hooper C., Tappeiner J.C.II., Ten-year growth response of young Douglas-fir to variable density varnishleaf ceanothus and herb competition, West. J. Appl. For. 14 (1999) 208-213.

[15] Nambiar E.K., Sands R., Competition for water and nutrients in forests, Can. J. For. Res. 23 (1993) 1955-1968.

[16] Newton M., Preest D.S., Growth and water relations of Douglas-fir (Pseudotsuga menziesii) seedlings under different weed control regimes, Weed Sci. 36 (1988) 653-662.

[17] Nilsson U., Orlander G., Vegetation management on grassdominated clearcuts planted with Norway spruce in southern Sweden, Can. J. For. Res. 29 (1999) 1015-1026.

[18] Nilsson U., Orlander G., Response to newly planted Norway spruce seedlings to fertilization, irrigation and herbicide treatments, Ann. For. Sci. 60 (2003) 637-643.

[19] O'Dea M.E., Newton M., Cole E.C., Gourley M., The influence of weeding on growth of browsed seedlings in Douglas-fir plantations, West. J. Appl. For. 15 (2000) 163-168.

[20] Petersen T.D., Newton M., Zedaker S.M., Influence of Ceanothus velutinus and associated forbs on the water stress and stemwood production of Douglas-fir, For. Sci. 34 (1988) 333-343.

[21] Powers R.F., Reynolds P.E., Ten-year responses of ponderosa pine plantations to repeated vegetation and nutrient control along an environmental gradient, Can. J. For. Res. 29 (1999) 1027-1038.

[22] Ritchie G.A., Tanaka Y., Meade R., Duke S.D., Field survival and early growth of Douglas-fir rooted cuttings: relationship to stem diameter and root system quality, For. Ecol. Manage. 60 (1993) 237-256.

[23] Rose R., Ketchum J.S., Interaction of vegetation control and fertilization on conifer species across the Pacific Northwest, Can. J. For. Res. 32 (2002) 136-152.

[24] Rose R., Morgan P., Guide to reforestation in western Oregon, Oregon State University For. Res. Lab. Res. Contr. 31, Corvallis, $2000,49 \mathrm{p}$.
[25] Rose R., Atkinson M., Gleason J., Sabin T., Root volume as a grading criterion to improve field performance of Douglas-fir seedlings, New For. 5 (1991) 195-209.

[26] Rose R., Gleason J.F., Atkinson M., Morphological and waterstress characteristics of three Douglas-fir stocktypes in relation to seedling performance under different soil moisture conditions, New For. 7 (1993) 1-17.

[27] Rose R., Haase D.L., Kroiher F., Sabin T., Root volume and growth of ponderosa pine and Douglas-fir seedlings: a summary of eight seasons, West. J. Appl. For. 12 (1997) 69-73.

[28] Rose R., Ketchum J.S., Hanson D.E., Three-year survival and growth of Douglas-fir seedlings under various vegetation-free regimes, For. Sci. 45 (1999) 117-126.

[29] Roth B.E., Newton M., Survival and growth of Douglas-fir in relation to weeding, fertilization and seed source, West. J. Appl. For. 11 (1996) 62-69.

[30] Smith D.M., The Practice of Silviculture, 8th Edition, John Wiley \& Sons, New York, 1986.

[31] South D.B., Mitchell R.J., Determining the "optimum" slash pine seedling size for use with four levels of vegetation management on a flatwoods site in Georgia, USA, Can. J. For. Res. 29 (1999) 10391046.

[32] South D.B., Mitchell R.J., Zutter B.R., Balneaves J.M., Barber B.L., Nelson D.G., Zwolinski J.B., Integration of nursery practices and vegetation management: economic and biological potential for improving regeneration, Can. J. For. Res. 23 (1993) 2083-2092.

[33] South D.B., Zwolinski J.B., Allen H.L., Economic returns from enhancing loblolly pine establishment on two upland sites: effects of seedling grade, fertilization, hexazinone and intensive soil cultivation, New For. 10 (1995) 239-256.

[34] South D.B., Rose R.W., McNabb K.L., Nursery and site preparation interaction research in the United States, New For. 22 (2001) 43-58.

[35] Strothmann R.O., Large stock and fertilizer improve growth of Douglas-fir planted on unstable granitic soil in northern California, USDA For. Serv. Pac. Southw. Res. Exp. Stn. Res. Note 345, 1980, $7 \mathrm{p}$

[36] Swindel B.F., Neary D.G., Comerford N.B., Rockwood D.L., Blakeslee G.M., Fertilization and competition control accelerate early southern pine growth on flatwoods, South. J. Appl. For. 12 (1998) 116-121.

[37] Tappeiner J.C. II, Hughes T.F., Tesch S.D., Bud production of Douglas-fir (Pseudotsuga menziesii) seedlings: response to shrub and hardwood competition, Can. J. For. Res. 17 (1987) 1300-1304.

[38] Tesch S.D., Hobbs S.D., Impact of shrub sprout competition on Douglas-fir seedling development, West. J. Appl. For. 4 (1989) $89-92$.

[39] Tiarks A.E., Haywood J.D., Pinus taeda L. response to fertilization, herbaceous plant control, and woody plant controle, For. Ecol. Manage. 14 (1986) 103-112.

[40] van den Driessche R., Late season fertilization, mineral nutrient reserves, and retranslocation in planted Douglas-fir (Pseudotsuga menziesii (Mirb.) Franco) seedlings, For. Sci. 31 (1985) 485-496.

[41] van den Driessche R., Absolute and relative growth of Douglas-fir seedlings of different sizes, Tree Physiol. 10 (1992) 141-152.

[42] Wagner R.G., Radosevich S.R., Interspecific competition and other factors influencing the performance of Douglas-fir saplings in the Oregon Coast Range, Can. J. For. Res. 21 (1991) 829-835.

[43] Wagner R.G., Mohammed G.H., Noland T.L., Critical period of interspecific competition for northern conifers associated with herbaceous vegetation, Can. J. For. Res. 29 (1999) 890-897.

[44] White D.E., Newton M., Herbaceous weed control in young conifer plantations with formulations of nitrogen and simazine, Can. J. For Res. 20 (1990) 1685-1689. 